\title{
Nutritional Screening for 2-5 Years Old Children in Urban and Rural Outpatient Settings
}

\author{
MOHAMED A. ABD EL WAHED, M.D.; MAY F. NASSAR, M.D.; AHMED K. AHMED, M.Sc. and \\ HEBA E. EL KHOLY, M.D.
}

The Department of Pediatrics, Faculty of Medicine, Ain Shams University, Cairo, Egypt

\begin{abstract}
Background: Malnutrition in children is common globally and may result in both short-and long-term irreversible negative health outcomes. Conventional indices fall short of portraying the full consequence of under-nutrition in the population. Screening Tool for Assessment of Malnutrition in Pediatric (STAMP) is another nutritional assessment tool which was created to solve this dilemma.
\end{abstract}

Aims of Study: This study was designed to detect any deviation of nutritional status of children from 2-5 years in outpatient clinic of rural and urban areas using conventional indices (weight for age, height for age and BMI), and the newly developed STAMP.

Patients and Methods: This cross-sectional study was conducted on 135 children aged 2-5 years attended the outpatient clinics in three hospitals, Bulaq El-Dakrur General Hospital (urban area), Al-Badrashin Central Hospital and AlWahat Al-Bahariya Hospital (rural areas), in Egypt. Weight and height measurements were obtained. Z-scores were calculated for weight-for-age (WAZ), height-for-age (HAZ) and BMI. World Health Organization growth charts were used to define underweight, stunted and obese patients and STAMP score was used to assess the risk for nutritional derangements. Dietary recall was also obtained and analyzed.

Results: Children were classified as per the conventional indices and STAMP. The prevalence of normal weight, height and BMI were $80 \%, 59.2 \%$ and $37.7 \%$ respectively. The prevalence of marginal underweight, marginal stunting and overweight were $17 \%, 27.4 \%$, and $34 \%$ respectively and the prevalence of underweight, stunting and obese were $2.9 \%$, $11.8 \%$, and $28.1 \%$ respectively. As per STAMP, $57 \%$ of children were at low risk, $17.7 \%$ were at intermediate risk and $25.1 \%$ were at high risk of malnutrition. Concerning the difference between urban and rural areas, the prevalence of underweight and stunting in urban district were $0.00 \%$ and $6.7 \%$ respectively, and in rural district were $4.4 \%$ and $14.4 \%$ respectively.

Conclusion: STAMP offers a valid screening tool for the detection of malnutrition and malnutrition risk in pediatric primary health care setting. It met the requirements of a nutrition screening tool in being quick and easy to use.

Correspondence to: Dr. Mohamed A. Abd El Wahed, E-Mail: dr.kamalo@live.com
Key Words: Malnutrition - Screening - Pediatrics - Outpatient - Urban and rural.

\section{Introduction}

THE American Society for Parenteral and Enteral Nutrition (ASPEN) workgroup defined pediatric malnutrition (under-nutrition) as "an imbalance between nutrient requirement and intake, resulting in cumulative deficits of energy, protein, or micronutrients that may negatively affect growth, development, and other relevant outcomes [1].

There are four various forms of malnutrition according to WHO classification: Underweight, stunting, wasting, and deficiencies in vitamins and minerals. Underweight is low weight-for-age, it can be associated with wasting, stunting, or both. Stunting is of low height for age and reflects chronic or recurrent malnutrition. Wasting is low weight-for-height and indicates recent and severe weight loss. Lastly, deficiencies in vitamins and minerals are known as micronutrient-related malnutrition and carry a real threat to children's health and development [2].

For a better understanding of the scope of the problem, malnutrition only is responsible for around 3.1 million child deaths annually in low and middleincome countries. The malnutrition is involved in about $45 \%$ of under-five children deaths in numerous developing countries. Thus, malnutrition is a vital health issue with significant magnitude [3] .

Globally in 2016, nearly 52 million, 17 million, and 155 million under-five children are wasted, severely wasted, and stunted, respectively. More than half of all stunted children under 5 live in Asia (56\%) and more than one third live in Africa $(38 \%)$. Also, more than two thirds of all wasted 
children under 5 live in Asia (69\%) and more than one quarter live in Africa (27\%) [4].

Concerning the difference between urban and rural areas as regards children's nutritional status, several studies documented that nutritional status of under-five children in the rural areas had a higher prevalence of wasting, stunting, and underweight than the urban areas. In Tangai district of Bangladesh prevalence of stunting, underweight and wasting was $(44.45 \%),(25 \%),(4.17 \%)$ respectively in the rural area, while in urban area, $(2.78 \%)$ were stunted, $(2.78 \%)$ were underweight and no one had wasting [5].

The importance of identifying children at increased nutritional risk has led to the development of many Nutritional Risk Screening (NRS) tools [6].

Until now no screening tool has shown absolute superiority over other tools. The development of specific screening tools for various specialties with appropriate reproducibility, when used by different professionals, is a necessity despite the difficulty to do that in practical scenarios. Accordingly, the selection of nutritional screening tools must be based on the appropriateness to specific health care facilities [7].

Some studies considered that the Pediatric Nutritional Risk Score (PNRS) is the most suitable for clinical practice since the results of high sensitivity and specificity in PNRS compared with Subjective Global Assessment (SGA) [8], however, both of these tools are relatively complicated and too time-consuming to use in screening [9] .

In the UK, the Screening Tool for the Assessment of Malnutrition in Pediatrics (STAMP) was established in 2004 and evaluated in 2007. To evaluate this quick and easy to-use Nutritional Screening Tools (NSTs) for hospitalized children, three factors were considered: Diagnosis, nutritional intake, as well as weight and height. After evaluating these factors, the sum was classified into low, medium, and high risk, and the STAMP also suggested a care plan in the last step [10]

STAMP offers a valid screening tool for the detection of malnutrition and malnutrition risk in a pediatric primary health care setting. Furthermore, the use of STAMP in a primary health care clinic raised clinician's awareness of nutritional status as indicated by an increase in anthropometric measurements and the documentation of nutritional status following study implementation [11].
Aim of the work:

This study was designed to detect any deviation of nutritional status of children from 2-5 years in outpatient clinic of rural and urban areas using conventional indices (weight for age, height for age and BMI), and the newly developed STAMP.

\section{Patients and Methods}

\section{Patients:}

This was a cross-sectional, observational, prospective study conducted in three different hospitals; El-Wahat Hospital, Bolaque El-Dakror Hospital, and El-Badrashine Hospital during the period from August 2018 to September 2019.

The study included 135 patients who were two to five years old and were clinically stable. We excluded hospitalized patients, patients with chronic diseases that affect nutrition and those whose parents refused to participate in the study.

\section{Methods:}

The sample size was calculated using EPIDAT software version 3.1. based on the results of the recent study of nutritional survey done in Fayoum, Egypt [3].

An informed verbal consent was obtained from caregivers before enrollment in the study according to the Faculty of Medicine, Ain Shams University Research Ethical Committee. All patients were then subjected to the following:

1-Full medical history including current complaints and chronic diseases, allergies and/or genetic disorders.

2- Thorough clinical examination to ensure the clinical stability of the patient.

3- Full anthropometric measures including:

- Weight (Wt) in Kg: Weight was measured by a beam a mechanical weight scale ZT-160. The child was weighed in light clothing without footwear. The values were plotted on growth curves according to official 2010 CDC growth charts, created by the National Center for Health Statistics (NCHS), Z score.

- Height (Ht) in cm: Height was measured by the stable stadiometer (Seca 217). The patient stood barefoot on the base plate, feet parallel, with heels, buttocks, shoulders, and back of head touching stadiometer. The head was held comfortably erect and the arms were hanging relaxed at the sides. The measuring arm was brought down on to the 
subject's head. The red cursor gave the accurate height measurement reading that was taken to the nearest millimeter. Percentages of medians were plotted on growth curves according to official 2010 CDC growth charts, created by NCHS and Zscores.

- Body mass index (BMI): Is the simplest parameter to assess nutritional status. BMI values were calculated using measured height and weight values as follows:

$$
\operatorname{BMI}\left(\mathrm{Kg} / \mathrm{m}^{2}\right)=\frac{\text { Weight }}{\text { (Height) }}{ }^{2}
$$

Table (1): A step-by-step guide to using STAMP.

\begin{tabular}{|c|c|c|c|}
\hline \multicolumn{4}{|c|}{ Step 1 - diagnosis } \\
\hline \multicolumn{3}{|c|}{$\begin{array}{l}\text { Does the child have a diagnosis that } \\
\text { has any nutritional implications? }\end{array}$} & Score \\
\hline \multirow{3}{*}{\multicolumn{2}{|c|}{$\begin{array}{l}\text { Definitely } \\
\text { Possibly } \\
\text { No }\end{array}$}} & \multicolumn{2}{|r|}{3} \\
\hline & & \multicolumn{2}{|r|}{2} \\
\hline & & \multicolumn{2}{|r|}{0} \\
\hline \multicolumn{4}{|c|}{ Step 2 - nutritional intake } \\
\hline \multicolumn{2}{|c|}{ What is the child's nutritional intake? } & \multicolumn{2}{|r|}{ Score } \\
\hline \multirow{3}{*}{\multicolumn{2}{|c|}{$\begin{array}{l}\text { None } \\
\text { Recently decreased/poor } \\
\text { No change/good }\end{array}$}} & \multicolumn{2}{|r|}{3} \\
\hline & & \multicolumn{2}{|r|}{2} \\
\hline & & \multicolumn{2}{|r|}{0} \\
\hline \multicolumn{4}{|c|}{ Step 3 - weight and height } \\
\hline \multicolumn{3}{|c|}{$\begin{array}{l}\text { Use a growth chart or the centile quick reference } \\
\text { tables to determine the child's measurements }\end{array}$} & Score \\
\hline \multicolumn{3}{|c|}{$\begin{array}{l}>3 \text { centile spaces } / \geq 3 \text { columns apart (or weight }<2 \text { nd } \\
\text { centile) }\end{array}$} & 3 \\
\hline \multirow{2}{*}{\multicolumn{2}{|c|}{$\begin{array}{l}>2 \text { centile spaces } /=2 \text { columns apart } \\
0 \text { to } 1 \text { centile spaces/columns apart }\end{array}$}} & & 1 \\
\hline & & & 0 \\
\hline \multicolumn{4}{|c|}{ Step 4 - overall risk of malnutrition } \\
\hline \multicolumn{3}{|c|}{$\begin{array}{l}\text { Add the scores from steps } 1-3 \text { together to } \\
\text { calculate the overall risk of malnutrition }\end{array}$} & Score \\
\hline \multirow{3}{*}{\multicolumn{2}{|c|}{$\begin{array}{l}\text { High risk } \\
\text { Medium risk } \\
\text { Low risk }\end{array}$}} & \multirow{3}{*}{\multicolumn{2}{|c|}{$\begin{array}{l}\geq 4 \\
2-3 \\
0-1\end{array}$}} \\
\hline & & & \\
\hline & & & \\
\hline \multicolumn{4}{|c|}{$\begin{array}{c}\text { Step } 5 \text { - care plan } \\
\text { Develop a care plan based on the child's overall risk of } \\
\text { malnutrition }\end{array}$} \\
\hline High risk & Medium risk & \multicolumn{2}{|c|}{ Low risk } \\
\hline $\begin{array}{l}\text { Take action Refer } \\
\text { to a Dietitian, } \\
\text { nutritional } \\
\text { support team or } \\
\text { consultant } \\
\text { Monitor as per } \\
\text { care plan }\end{array}$ & $\begin{array}{l}\text { Monitor nutritional } \\
\text { intake for } 3 \text { days } \\
\text { Repeat STAMP } \\
\text { screening after } 3 \\
\text { days Amen d care } \\
\text { plan as required }\end{array}$ & \multicolumn{2}{|c|}{$\begin{array}{l}\text { Continue routine } \\
\text { clinical care } \\
\text { Repeat STAMP } \\
\text { screening weekly } \\
\text { while the child is } \\
\text { an in-patient } \\
\text { Amend care plan } \\
\text { as required }\end{array}$} \\
\hline
\end{tabular}

The anthropometric evaluation was done using methods adopted by the World Health Organization (WHO), anthropometric standards recommended by the Centers for Disease Control and Prevention (CDC) 2010 created by National Center for Health Statistics (NCHS) and Z score [12]

4- Three days 24-hours diet recall was taken and analyzed through software program based on food composition table of (National Nutrition Institute) NNI 2010. An Arabic version that analyzed the input of $24 \mathrm{hr}$ dietary recall into detailed macro and micronutrient analysis had been used. Dietary recall included: Breakfast, snacks, lunch, and dinner of the previous 24 hours. The average of the three sheets was taken.

5- Energy gap was estimated upon which nutritional advices were given to the patients.

6- All patients were screened with STAMP (Table 1) $[10]$

\section{Results}

Number of total study population was 135 patients arranged into 3 equal groups (each one included 45 children) according to the area of the recruitment hospital (group El-Wahat, El-Badrashine and Bolaqu). The age of the studied patients ranged from 2 to 5 years with a mean \pm SD of $3.50 \pm 0.95$ years. Regarding sex distribution, there were 66 females $(48.9 \%)$ and 69 males $(51.1 \%)$ as shown in (Table 2). Table (2) also shows no significant difference between the three groups as regarding age. Concerning sex distribution, each group involved 22 females with percentage $48.9 \%$ and 23 males with percentage $51.1 \%$ with no significant difference between the three groups (Table 2).

On comparing the three groups as regards anthropometric measures (Table 3), there was no significant difference as regards weight, weight $Z$ score and height measurement. Regarding the height $\mathrm{Z}$ score, there was a significant difference between the three groups with a $p$-value of 0.025 . El-Badrashine Hospital showed a higher number of patients [9 (20\%)] who were stunted, compared to $4(8.9 \%)$ in El-Wahat and $3(6.7 \%)$ in Bolaqu. Also, El-Badrashine Hospital showed 2 patients (4.4\%) were severely stunted, while no patients were severely stunted at Bolaque and El-Wahat hospital. Regarding BMI, there was a significant difference between the three groups with a $p$-value of 0.043. El-Wahat Hospital showed higher BMI with a mean \pm SD of $16.58 \pm 1.44$ and range of 13.320.1 , while El-Badrashinethe BMI mean $\pm \mathrm{SD}$ was $16.26 \pm 1.48$ and the range was 13.3-20.9, and 
Bolaque Hospital was the least one with BMI mean \pm SD of $15.86 \pm 1.09$ and range of 13.9-18.9. BMI $\mathrm{Z}$ score showed no significant differences.

Although STAMP score showed no significant difference between the three groups, Bolaque group had a higher number of patients who were at low risk [32 (71.1\%)], El-Badrashine group showed a higher number of patients who were at high risk [16 (35.6\%)], and El-Wahat group had a higher number of patients who were at intermediate risk [12 (26.7\%)]. As shown in Fig. (1), patients at low risk, were $71.1 \%$ of patients in Bolaque, $53.3 \%$ in El-Wahat, and $46.7 \%$ in El-Badrashine. While, $8.9 \%$ of patients in Bolaque, $26.7 \%$ in El-Wahat, and $17.8 \%$ in El-Badrashine were at intermediate, risk. Finally, $20 \%$ of patients in Bolaque, $20 \%$ in El-Wahat, and $35.6 \%$ in El-Badrashine were at high risk.

Comparison between the three groups as regards nutritional analysis showed no significant difference between the three groups, however highest intake of all elements was found in Bolague Hospital except for potassium and zinc, which were highest in El-Wahat Hospital as demonstrated in (Table 4).
Table (2): Age and sex distribution among the study population.

\begin{tabular}{cl}
\hline & No. $=135$ \\
\hline Sex: & \\
Females & $66(48.9 \%)$ \\
Males & $69(51.1 \%)$ \\
Age (years): & \\
Mean \pm SD & $3.50 \pm 0.95$ \\
Range & $2-5$ \\
\hline
\end{tabular}

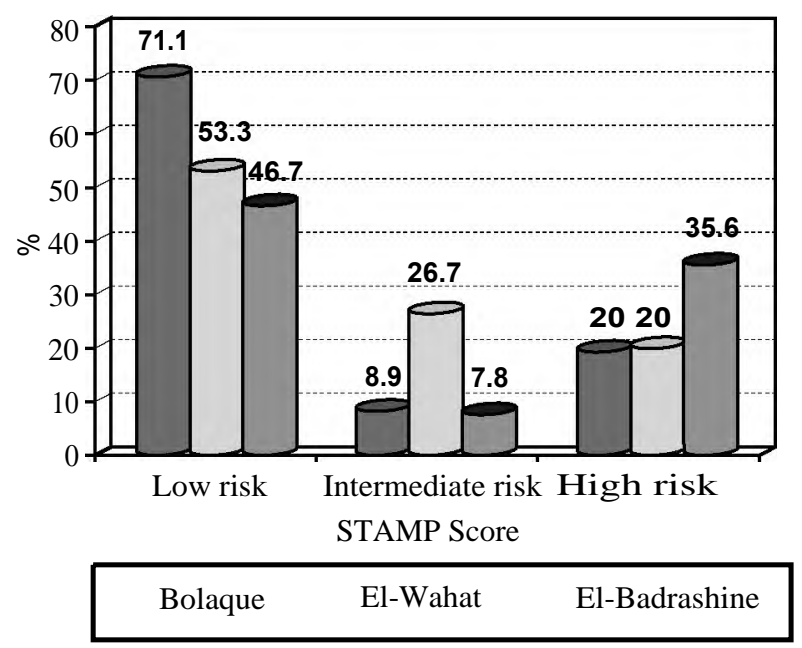

Fig. (1): Comparison between the three groups in the first visit as regards STAMP score.

Table (3): Comparison between the three groups as regards anthropometric measurements.

\begin{tabular}{|c|c|c|c|c|c|c|}
\hline & $\begin{array}{l}\text { Bolaque } \\
\text { No. }=45\end{array}$ & $\begin{array}{l}\text { El-Wahat } \\
\text { No. }=45\end{array}$ & $\begin{array}{c}\text { El-Badrashine } \\
\text { No. }=45\end{array}$ & $\begin{array}{c}\text { One way } \\
\text { ANOVA Test }\end{array}$ & $\begin{array}{c}p- \\
\text { value }\end{array}$ & Sig \\
\hline \multicolumn{7}{|l|}{ Weight $(\mathrm{kg})$ : } \\
\hline Mean \pm SD & $15.17 \pm 2.90$ & $15.42 \pm 2.71$ & $14.19 \pm 2.44$ & 2.636 & 0.075 & NS \\
\hline Range & $10.2-21.5$ & $11-21$ & $10.4-20$ & & & \\
\hline \multicolumn{7}{|l|}{ Weight Z score: } \\
\hline Marginal underweight & $7(15.6 \%)$ & $6(13.3 \%)$ & $10(22.2 \%)$ & 3.519 & 0.475 & NS \\
\hline Underweight & $0(0.0 \%)$ & $2(4.4 \%)$ & $2(4.4 \%)$ & & & \\
\hline Normal & $38(84.4 \%)$ & $37(82.2 \%)$ & $33(73.3 \%)$ & & & \\
\hline \multicolumn{7}{|l|}{ Height $(\mathrm{cm})$ : } \\
\hline Mean \pm SD & $97.46 \pm 8.82$ & $96.02 \pm 7.94$ & $93.26 \pm 8.07$ & 2.988 & 0.054 & NS \\
\hline Range & $80-113$ & $81-117$ & $71.5-109$ & & & \\
\hline \multicolumn{7}{|l|}{ Height Z score: } \\
\hline Normal & $34(75.6 \%)$ & $27(60.0 \%)$ & $19(42.2 \%)$ & 14.424 & 0.025 & S \\
\hline Marginally stunted & $8(17.8 \%)$ & $14(31.1 \%)$ & $15(33.3 \%)$ & & & \\
\hline Stunted & $3(6.7 \%)$ & $4(8.9 \%)$ & $9 \quad(20.0 \%)$ & & & \\
\hline Severely stunted & $0(0.0 \%)$ & $0(0.0 \%)$ & $2(4.4 \%)$ & & & \\
\hline \multicolumn{7}{|l|}{ BMI: } \\
\hline Mean \pm SD & $15.86 \pm 1.09$ & $16.58 \pm 1.44$ & $16.26 \pm 1.48$ & 3.215 & 0.043 & $\mathrm{~S}$ \\
\hline Range & $13.9-18.9$ & $13.3-20.1$ & $13.3-20.9$ & & & \\
\hline \multicolumn{7}{|l|}{ BMI Z score: } \\
\hline Normal & $22(48.9 \%)$ & $13(28.9 \%)$ & $16(35.6 \%)$ & 8.196 & 0.085 & NS \\
\hline Overweight & $17(37.8 \%)$ & $15(33.3 \%)$ & $14(31.1 \%)$ & & & \\
\hline Obese & $6 \quad(13.3 \%)$ & $17(37.8 \%)$ & $15(33.3 \%)$ & & & \\
\hline
\end{tabular}


Table (4): Comparison between the three groups as regards the nutritional analysis.

\begin{tabular}{|c|c|c|c|c|c|c|}
\hline $1{ }^{\text {st }}$ visit & & & $\begin{array}{l}\text { El-Badrashine } \\
\text { No. }=45\end{array}$ & $\begin{array}{l}\text { One way } \\
\text { ANOVA Test }\end{array}$ & $\begin{array}{c}\mathrm{p}- \\
\text { value }\end{array}$ & Sig. \\
\hline $\begin{array}{l}\text { Calories: } \\
\text { Mean } \pm \text { SD } \\
\text { Range }\end{array}$ & $\begin{array}{l}1282.85 \pm 542.53 \\
344-2334\end{array}$ & $\begin{array}{l}1208.10 \pm 567.88 \\
213.8-2716.6\end{array}$ & $\begin{array}{l}1188.44 \pm 409.13 \\
354.6-2505.4\end{array}$ & 0.427 & 0.653 & NS \\
\hline $\begin{array}{l}\text { Sodium: } \\
\text { Mean } \pm \text { SD } \\
\text { Range }\end{array}$ & $\begin{array}{l}2265.54 \pm 1399.63 \\
414-6003.7\end{array}$ & $\begin{array}{l}2308.11 \pm 1575.72 \\
310.8-6736.5\end{array}$ & $\begin{array}{l}2170.46 \pm 1280.20 \\
269.2-6855.8\end{array}$ & 0.110 & 0.896 & NS \\
\hline $\begin{array}{l}\text { Ph: } \\
\quad \text { Mean } \pm \text { SD } \\
\text { Range }\end{array}$ & $\begin{array}{l}479.24 \pm 249.65 \\
82.7-1204.6\end{array}$ & $\begin{array}{l}371.36 \pm 198.38 \\
48.4-840.9\end{array}$ & $\begin{array}{l}446.22 \pm 208.42 \\
61.6-922.8\end{array}$ & 2.842 & 0.062 & NS \\
\hline $\begin{array}{l}\text { CHO: } \\
\text { Mean } \pm \text { SD } \\
\text { Range }\end{array}$ & $\begin{array}{l}186.32 \pm 94.39 \\
18.1-387.5\end{array}$ & $\begin{array}{l}167.67 \pm 90.00 \\
28.6-398.7\end{array}$ & $\begin{array}{l}171.63 \pm 67.32 \\
37.6-375.2\end{array}$ & 0.605 & 0.548 & NS \\
\hline $\begin{array}{l}\text { K: } \\
\quad \text { Mean } \pm \text { SD } \\
\text { Range }\end{array}$ & $\begin{array}{l}1443.30 \pm 666.72 \\
634-3308.8\end{array}$ & $\begin{array}{l}1523.83 \pm 747.76 \\
279.3-3410\end{array}$ & $\begin{array}{l}1516.23 \pm 569.58 \\
490.7-3028\end{array}$ & 0.201 & 0.818 & NS \\
\hline $\begin{array}{l}\text { Ca: } \\
\quad \text { Mean } \pm \text { SD } \\
\text { Range }\end{array}$ & $\begin{array}{l}675.72 \pm 387.05 \\
71.9-1636.2\end{array}$ & $\begin{array}{l}634.25 \pm 504.27 \\
16.6-2541.3\end{array}$ & $\begin{array}{l}535.41 \pm 374.70 \\
56.7-1334.5\end{array}$ & 1.288 & 0.279 & NS \\
\hline $\begin{array}{l}\text { Fat: } \\
\quad \text { Mean } \pm \text { SD } \\
\text { Range }\end{array}$ & $\begin{array}{l}36.98 \pm 14.18 \\
16.2-68.7\end{array}$ & $\begin{array}{l}36.70 \pm 15.30 \\
5.4-69.4\end{array}$ & $\begin{array}{l}34.57 \pm 12.76 \\
14.9-66.2\end{array}$ & 0.391 & 0.677 & NS \\
\hline $\begin{array}{l}\text { Water: } \\
\text { Mean } \pm \text { SD } \\
\text { Range }\end{array}$ & $\begin{array}{l}473.42 \pm 191.44 \\
130.1-935\end{array}$ & $\begin{array}{l}440.44 \pm 224.95 \\
37.3-1110.6\end{array}$ & $\begin{array}{l}447.65 \pm 180.59 \\
72.9-824.6\end{array}$ & 0.338 & 0.714 & NS \\
\hline $\begin{array}{l}\text { Zinc: } \\
\quad \text { Mean } \pm \text { SD } \\
\text { Range }\end{array}$ & $\begin{array}{l}7.31 \pm 3.89 \\
1.2-15.3\end{array}$ & $\begin{array}{l}8.40 \pm 14.17 \\
0.53-97.9\end{array}$ & $\begin{array}{l}7.01 \pm 3.05 \\
1.8-15.9\end{array}$ & 0.323 & 0.724 & NS \\
\hline $\begin{array}{l}\text { Iron: } \\
\quad \text { Mean } \pm \text { SD } \\
\text { Range }\end{array}$ & $\begin{array}{l}10.69 \pm 9.02 \\
0.8-50.8\end{array}$ & $\begin{array}{l}8.14 \pm 4.66 \\
0.78-19\end{array}$ & $\begin{array}{l}9.55 \pm 5.82 \\
2.2-27.12\end{array}$ & 1.605 & 0.205 & NS \\
\hline $\begin{array}{l}\text { Fiber: } \\
\quad \text { Mean } \pm \text { SD } \\
\text { Range }\end{array}$ & $\begin{array}{l}4.43 \pm 3.08 \\
0.3-13.1\end{array}$ & $\begin{array}{l}4.87 \pm 3.46 \\
0.25-13.6\end{array}$ & $\begin{array}{l}4.71 \pm 2.76 \\
1.2-13.9\end{array}$ & 0.232 & 0.794 & NS \\
\hline $\begin{array}{l}\text { Protein: } \\
\text { Mean } \pm \text { SD } \\
\text { Range }\end{array}$ & $\begin{array}{l}51.35 \pm 23.56 \\
12-104.7\end{array}$ & $\begin{array}{l}45.55 \pm 24.43 \\
2.6-122.3\end{array}$ & $\begin{array}{l}48.67 \pm 19.24 \\
11.7-107.2\end{array}$ & 0.746 & 0.476 & NS \\
\hline
\end{tabular}

\section{Discussion}

Malnutrition is a significant problem in Egypt despite the immense efforts to provide nutritional support to deal with malnutrition in the last years. Many studies tackled the numerous issues of malnutrition in young children in Egypt recently [3] This attention to malnutrition was developed after recognizing that almost $50 \%$ of the mortality in young children is attributable to malnutrition which is nearly 3 million children per year [13]

Additionally, rapid identification of malnourished children is of clinical importance as malnutrition is associated with poorer outcomes and increased healthcare costs. Also, childhood malnutrition is associated with poorer somatic growth and development, reduced or delayed mental and psychomotor development [14].

Therefore, the study of the prevalence of malnutrition and prevention of malnutrition should be given a high priority in the primary health care programs with particular attention paid to the rural population. In this study, 135 patients were selected from the outpatient clinics of three different hospitals in rural and urban districts. All patients were screened by STAMP and nutritional rehabilitation program was designed then nutritional response testing was performed by reassessment. 
The prevalence of stunting in the total study sample was $11.8 \%$. Similar results were documented in Egypt in other studies. In Alexandria $15 \%$ of 1,217 preschool children were stunted as reported by El-Sayed et al., [15]. Higher prevalence was documented in a study which took place in Cairo as $58.4 \%$ of 500 children under 3 years were stunted [16]. Also, in Yemen higher prevalence was documented, with $38.5 \%$ of 1292 children under 5 year were stunted [13]. In India, the prevalence of stunting among 400 under-five children was $36.5 \%$ in the urban slums [17].

Also, there was a significant difference between urban area (represented at Bolaqu Hospital) and rural area (represented at El-Wahat and El-Badrashine Hospital) as regards stunting and stunting was found to be higher in the rural area. There were $6.7 \%$ stunted cases in urban bolaqu as well as $8.9 \%$ and $20 \%$ among rural areas in El-Wahat and El-Badrashine, respectively, with $14.4 \%$ overall stunting in rural area. Similarly, a significant difference between urban and rural prevalence of stunting was documented in Ethiopia, with $24 \%$ among urban children and $42 \%$ among rural children [18]. Also, in Nigeria, the prevalence of stunting in the rural and the urban communities were $35.8 \%$ and $19.8 \%$, respectively [19].

Concerning underweight, $2.9 \%$ of children in the total study sample were underweight, which was also shown in another study done in Egypt, where $5.5 \%$ of under-five children were underweight [3]. A slight higher prevalence was documented in Alexandria where $7.3 \%$ of 1,217 preschool children were underweight [15]. Higher prevalence was documented in Ethiopia, as $26.7 \%$ out of 4,893 under-five children were underweight [18]. Also, in Cairo, $62.4 \%$ of 500 children under 3 years were underweight [16].

Concerning the difference between urban and rural areas as regard underweight, rural areas had higher numbers of underweight children, although there was no significant difference between them. At urban Bolaqu Hospital, there were no underweight children, while in the two rural areas showed the same prevalence (4.4\%). Also, in Ethiopia, there was a higher number of underweight children in rural area compared to urban area, as the prevalence of underweight in rural and urban was $27 \%$ and $13 \%$, respectively [18], and in Nigeria, $70.5 \%$ were underweight in rural and $52.2 \%$ in urban [19]

As for BMI, the total study sample showed that $34 \%$ are overweight and $28.1 \%$ are obese. lower prevalence was documented in Alexandria by Sala- ma and Tayel [20] as $14 \%$ of their 500 studied 25 years old children were overweight and $23 \%$ were obese.

Comparing between rural and urban areas as regards overweight and obesity, in the urban area, there was higher number of overweight $(37.8 \%)$, compared to rural areas in El-Wahat and ElBadrashine (33.3\% and 31.1\% respectively) with an overall prevalence of $32.2 \%$. Similarly, in Tangai district of Bangladesh, overweight was higher in urban $(5.5 \%)$ than in rural areas where no children were found to be overweight [5].

Concerning obesity, it was higher in rural areas than urban area. In El-Wahat and El-Badrashine, $37.8 \%$, and $33.3 \%$ were obese respectively, compared to $13.3 \%$ in the urban area with overall prevalence of $35.5 \%$. Davis et al., [21] explained this finding by the fact that rural children do not engage in physical activity as much as urban children. Contrary to this finding, $4.17 \%$ were obese in the urban area and no children were obese in the rural area of Tangai district in Bangladesh [5]

Among the 135 patients screened by STAMP, $17.7 \%$ were found to be nutritionally at risk $($ STAMP $\geq 2$ ), and $25.1 \%$ at high risk (STAMP $\geq 4$ ). However, McCarthy et al., [10] in England, reported STAMP identified $14 \%$ of 238 children aged from 2 to 17 years as being at nutritional risk (STAMP $\geq 2$ ) and $18 \%$ with a score of 4 or greater [10]. This comes in disagreement with a study in UK's Stoke Mandeville Hospital as $58.8 \%$ of 51 children were found to be nutritionally at risk and $23.5 \%$ were at high risk [22]. The prevalence of STAMP is different between the current study and other studies due to poor health conditions of children in other studies, as the study sample was collected from hospital admitted children, unlike our study.

Concerning daily caloric (Kcal) intake, in urban area mean caloric intake was $1282.85 \pm 542.53$,

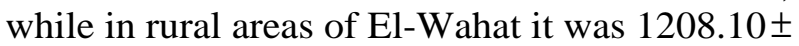
567.88 and in El-Badrashineit was $1188.44 \pm$ 409.13. In the other studies, different results were documented, in Mkushi, a rural district area in central Zambia total calories was $1469 \mathrm{Kcal}$ among children aged from 4 to 8 years [23].

As regards protein intake in grams, in the urban area was $51.35 \pm 23.56$, and in rural areas of ElWahat it was $45.55 \pm 24.43 \mathrm{SD}$ and in EL-Badrashine it was $48.67 \pm 19.24 \mathrm{SD}$. Similar result was documented in Mkushi as daily protein intake was 47 g among children aged from 4 to 8 years [23] Nevertheless, in urban Dakar in Senegal, lower 
protein intake was documented (36 $\pm 1 \mathrm{SD})$ among children aged from 5 to 17 years [24].

Regarding CHO intake in grams, the urban area was 186.32 \pm 94.39 , and in rural areas of El-Wahat it was $167.67 \pm 90.00$ and in El-Badrashine it was 171.63 \pm 67.32. Similarly, in urban Dakar in Senegal $\mathrm{CHO}$ intake was $176 \pm 3$ for children aged from 5 to 17 years [24]. On the contrary, in Mkushi CHO intake was $222 \mathrm{~g}$ among children aged from 4 to 8 years [23]

Concerning fat intake in grams, the studied urban area showed fat intake of $36.98 \pm 14.18$, and in rural area of El-Wahat it was 36.70 \pm 15.30 , and in El-Badrashine it was $34.57 \pm 12.76$. On the contrary, a study conducted in Accra, Ghana, among children aged from 6 to 19 years showed that the mean intake of fats was $44.74 \pm 20.22$, which was higher than the RDA [25].

As regards fiber intake in grams, the studied urban area showed mean fiber intake of $4.43 \pm 3.08$, and rural areas in El-Wahat it was $4.87 \pm 3.46$ and in El-Badrashine it was $4.71 \pm 2.76$. This is nearly half the reported fiber intake in Libya, as average daily intake was $10 \mathrm{~g} /$ day among 550 children aged from 6 to 9 years [26].

Regarding Ca intake in milligrams, the studied urban area showed mean Ca intake of 675.72 \pm 387.05 , and in the rural area in El-Wahat it was $634.25 \pm 504.27$ and in El-Badrashine it was 535.41 \pm 374.70. This comes in disagreement with a study done in Mkushi as lower Ca intake was documented (263mg) among children aged from 4 to 8 years [23] but Murphy et al., [27] documented a higher level of Ca intake (999mg) among children aged from 2 to 4 years in Washington (U.S).

Concerning iron intake in milligrams, the studied urban area showed mean iron intake of $10.69 \pm$ 9.02, and in the rural area in El-Wahat it was $8.14 \pm$ 4.66 and in El-Badrashine it was $9.55 \pm 5.82$. Similarly, in Mkushi, mean iron intake was $(8.8 \mathrm{mg})$ [23]. This comes in disagreement with iron intake in Valencia, Spain where iron intake showed a mean of $11.66 \pm 4.08$ among children aged from 6 to 9 years [28]

As regards zinc intake in milligrams, the studied urban area showed mean of $7.31 \pm 3.89$, and in the rural area in El-Wahat it was 8.40 \pm 14.17 and in El-Badrashie it was $7.01 \pm 3.05$. Close results were reported in Valencia, where zinc intake was $9.44 \pm$ 2.50 among children aged from 6 to 9 years [28], while in Mkushi the intake was 5.9mg [23].
Regarding $\mathrm{Ph}$ intake in milligrams, the studied urban area showed mean of $479.24 \pm 249.65$, and in the rural area of El-Wahat it was 371.36 \pm 198.38 and in El-Badrashine it was 446.22 \pm 208.42 . A different result was documented in Valencia, Spain as $\mathrm{Ph}$ intake showed a mean of $1274.12 \pm 277.42$ among children aged from 6 to 9 years [28]

Concerning sodium intake, the studied urban area showed a mean of $2265.54 \pm 1399.63$, and in the rural area El-Wahat it was $2308.11 \pm 1575.72$ and in El-Badrashine it was 2170.46 \pm 1280.20 . Higher values were reported in Baltimore City, Canada as sodium intake showed a mean of 3144 among children aged from 5 to 8 years [29].

As regards $\mathrm{K}$ intake, the studied urban area showed mean of $1443.30 \pm 666.72$ and in the rural area El-Wahat it was $1523.83 \pm 747.76$, and in ElBadrashine it was $1516.23 \pm 569.58$. On the contrary, Murphy et al., [27] documented a higher level of K intake (2184mg) among children aged from 2 to 4 years in Washington (U.S).

We are one of the fewest studies which used STAMP in the outpatient ward, in addition to Rub et al., [11] who also used STAMP in primary health care sitting and also proved that STAMP offers a valid screening tool for the detection of malnutrition and malnutrition risk in pediatric primary health care setting. Other studies used STAMP on hospitalized children, [10,22,30,31]

Several studies used nutritional screening tools in outpatient sittings like Joosten et al., [32] who used STRONG-Kids tool in primary schools for chronically ill children. Also, Nutrition Screening Tool for Every Preschooler (NutriSTEP) was developed to determine the nutrition risk of the general preschool population [33]

Regarding difference between STAMP and other screening tools, Ling et al., [34] reported that STAMP correlates less closely to anthropometry than STRONGKIDS and STAMP identifies a considerably greater number of children who are receiving no nutritional support as being at high risk than STRONGKIDS. Also, Moeeni et al., [35] reported STAMP tool defined the highest number of children as medium and high risk, in contrast to PYMS which classified fewer number.

\section{Conclusion:}

In conclusion STAMP is quick and easy to use, requiring no nutritional expertise and minimal training to implement. Urban children generally have better nutritional status than their rural counterparts who suffered mainly from stunting more 
than under-weight. We recommend further studies to demonstrate the benefits of nutritional screening in children in terms of reducing the prevalence of mal-nutrition and the related morbidity and mortality, as well as the health economic implications of nutrition risk.

\section{References}

1- MEHTA N.M., CORKINS M.R., LYMAN B., MALONE A., GODAY P., NIEMAN L., MONCZKA J., PLOGSTED S. and SCHWENK W.F.: Defining pediatric malnutrition: A paradigm shift toward etiology-related definitions. JPEN J. Parenter. Enteral. Nutr., 37 (4): 460-81, 2013.

2- CEDERHOLM T., BARAZZONI R., AUSTIN P., BALLMER P., BIOLO G., BISCHOFF S.C., COMPHER C., CORREIA I., HIGASHIGUCHI T., HOLST M., JENSEN G.L., MALONE A., MUSCARITOLI M., NYULASI I., PIRLICH M., ROTHENBERG E., SCHINDLER K., SCHNEIDER S.M., De VAN DER SCHUEREN M.A.E., SIEBER C., VALENTINI L., YU J.C.,VAN GOSSUM A. and SINGER P.: ESPEN guidelines on definitions and terminology of clinical nutrition. Clinical nutrition, 36 (1): 49-64, 2017.

3- ELSARY A.Y., ABD EL-MOKTADER A.M., ELGAMEEL A., MOHAMMED W.S., MASOUD M. and ABD EL-HALEEM N.G.: Nutritional survey among under five children at Tamyia district in Fayoum, Egypt. Int. J. Community Med. Public Health, 4 (6): 1813-8, 2017.

4- UNICEF, World Health Organization \& World Bank Group: Levels and Trends in Child Malnutrition. UNICEF/ WHO/World Bank Group Joint Child Malnutrition Estimates: Key findings of the 2017 edition, 2017.

5- ISLAM M.D., JOTHI J.S., ISLAM M. and OBIDUL HUQ A.K.: Nutritional Status of Rural and Urban Under-Five Children in Tangail District, Bangladesh. International Journal of Innovation and Applied Studies, 8 (2): 841-8, 2014.

6- HUYSENTRUYT K., ALLIET P., MUYSHONT L., ROSSIGNOL R., DEVREKER T., BONTEMS P., DEJONCKHEERE J., VANDENPLAS Y. and SCHEPPER J.D.: The STRONG (kids) nutritional screening tool in hospitalized children: A validation study. Nutrition, 29 (11-12): 135631, 2013.

7- LEE Y.L.: Nutritional Screening Tools among Hospitalized Children: From Past and to Present. Pediatr. Gastroenterol. Hepatol. Nutr., 21 (2): 79-85, 2018.

8- LESTARI N.E., NURHAENI N. and WANDA D.: The pediatric yorkhill malnutrition score is a reliable malnutrition screening tool. Compr. Child Adolesc. Nurs., 40 (1): 62-8, 2017.

9- HULST J.M., ZWART H., HOP W.C. and JOOSTEN K.F.: Dutch national survey to test the STRONGkids nutritional risk screening tool in hospitalized children. Clinical Nutrition, 29 (1): 106-11, 2010.

10- McCARTHY H., DIXON M., CRABTREE I., EATONEVANS M.J. and McNULTY H.: The development and evaluation of the Screening Tool for the Assessment of Malnutrition in Paediatrics (STAMP $\odot$ ) for use by healthcare staff. J. Hum. Nutr. Diet., 25 (4): 311-8, 2012.
11-RUB G., MARDERFELD L., PORAZ I., HARTMAN C., AMSEL S., ROSENBAUM I., PERGAMENTZEV-KARPOL S., MONSONEGO-ORNAN E. and SHAMIR R.: Validation of a Nutritional Screening Tool for Ambulatory Use in Pediatrics. J. Pediatrics gastroenterology nutrition, 62 (5): 771-5, 2016.

12- Centers for Disease Control and Prevention: Use of the World Health Organization and CDC growth charts for children aged 0-59 months in the United States. MMWR Recomm. Rep., 59 (9): 1-15, 2010.

13- AL-SADEEQ A., BUKAIR A. and AL-SAQLADI A.W.: Assessment of undernutrtion using composite Index of Anthropometric Failure among children aged $<5$ years in rural Yemen. East Mediterr. Health J., 24 (12): 1119-26, 2018.

14- BROTHERTON A., SIMMONDS N., BOWLING T. and STROUD M.: Malnutrition is dangerous: The importance of effective nutritional screening and nutritional care. Journal of Patient Safety and Risk Management, 17 (4): 137-42, 2011

15- EL-SAYED N., MOHAMED A.G., NOFAL L., MAHFOUZ A. and ZEID H.A.: Malnutrition among school children in Alexandria. J. Health Popul. Nutr., 19 (4): 275-80, 2001.

16- SHAABAN S., NASSAR M., EL-GENDY Y. and ELSHAER B.: Nutritional risk screening of hospitalized children aged <3 years. East Mediterr. Health J., 25 (1): 18-23, 2019.

17-KIRAN S.A., LALIT R.S. and SULABHA V.A.: Magnitude of malnutrition among underfive children in urban slums of commercial capital of India and its multifactorial causation: A community-based study. J. Family Med. Prim. Care, 8 (12): 3865-70, 2019.

18- Central Statistical Agency: Ethiopia Mini Demographic and Health Survey 2014. Addis Ababa, Ethiopia: CSA; 2014.

19- ONINLA S.O., OWA J.A., ONAYADE A.A. and TAIWO O.: Comparative study of nutritional status of urban and rural Nigerian school children. Journal of Tropical Paediatrics, 53 (1): 39-43, 2007.

20- SALAMA A.A. and TAYEL D.I.: Overweight and Obesity among Preschool Children aged 2-5 Years in Alexandria, Egypt. Canad J. Clin. Nutr., 6 (1): 34-54, 2018.

21- DAVIS A.M., BENNET K.J., BEFORT C. and NOLLEN N.: "Obesity and Related Health Behaviors among Urban and Rural Children in the United States: Data from the National Health and Nutrition Examination Survey 20032004 and 2005-2006, J. Pediatric Psychl., 36 (6): 66976, 2010.

22- WONG S., GRAHAM A., HARINI S.P., GRIMBLE G. and FORBES A.: Validation of the Screening Tool for the Assessment of Malnutrition in Paediatrics (STAMP) in patients with spinal cord injuries (SCIs). E. pub., 51 (5): 424-9, 2013.

23- CASWELL B.L., TALEGAWKAR S.A., DYER B., SIAMUSANTU W., KLEMM R.D. and PALMER A.C.: Assessing Child Nutrient Intakes Using a Tablet-Based 24Hour Recall Tool in Rural Zambia. Food \& Nutrition Bulletin, 36 (4): 467-80, 2015. 
24- FIORENTINO M., LANDAIS E., BASTARD G., CARRIQUIRY A., WIERINGA F.T. and BERGER J.: Nutrient Intake Is Insufficient among Senegalese Urban School Children and Adolescents: Results from Two 24h Recalls in State Primary Schools in Dakar. Nutrients, 8 (10): 650, 2016.

25- INTIFUL F.D., OGYIRI L., ASANTE M., MENSAH A.A., STEELE-DADZIE R. and BOATENG L.: Nutritional status of boarding and non-boarding children in selected schools in the Accra metropolis. J. Biol. Agric. Healthc., 3 (7): 156-62, 2013.

26- ELHISADI T.A.: Food and nutrients intake among Libyan school children. Sci. J. Med. Clin. Trial.Volume: 146-4, 2013.

27- MURPHY S.P., YAKTINE A.L., SUITOR C.W. and MOATS S.: Institute of Medicine (US) Committee to Review Child and Adult Care Food Program Meal Requirements. Aligning Dietary Guidance for All. Washington, DC: The National Academies Press 2011.

28- MORALES-SUÁREZ-VARELA M., RUBIO-LÓPEZ N., RUSO C., LLOPIS-GONZALEZ A., RUIZ-ROJO E., REDONDO M. and PICO Y.: Anthropometric Status and Nutritional Intake in Children (6-9 Years) in Valencia (Spain): The ANIVA Study. Int. J. Environ. Res. Public Health, 12 (12): 16082-95, 2015.

29- KOLAHDOOZ F., BUTLER J.L., CHRISTIANSEN K., DIETTE G.B., BREYSSE P.N., HANSEL N.N., McCORMACK M.C., SHEEHY T., GITTELSOHN J. and SHARMA S.: Food and Nutrient Intake in African American
Children and Adolescents Aged 5 to 16 Years in Baltimore City. J. Am. Coll. Nutr., 35 (3): 205-16, 2016.

30- LAMA MORE R.A., LÓPEZ A.M., ÁLVAREZ M.H., CHICANO S.C., MARTÍNEZ R.G., RUZAFA E.L., MARTÍNEZ G.R., HERNÁNDEZ A.D. and De La ROSA M.C.: Validación de una herramienta de cribado nutricional para pacientes pediátricos hospitalizados. Nutr. Hosp., 27 (5): 1429-36, 2012.

31- WONOPUTRI N., DJAIS J.T. and ROSALINA I.: Validity of nutritional screening tools for hospitalized children. J. Nutr. Metab., 31 (4): 313-21, 2014.

32- JOOSTEN K., VAN DER VELDE K., JOOSTEN P., RUTTEN H., HULST J. and DULFER K.: Association between nutritional status and subjective health status in chronically ill children attending special schools. Qual. Life Res., 25 (4): 969-77, 2016.

33- CARDUCCI B., REESOR M., HARESIGN H., RYSDALE L., KELLER H., BEYERS J., PAQUETTE-DUHAIME S., O'CONNOR A. and SIMPSON J.R.: NutriSTEP® is Reliable for Internet and Onscreen Use. Can. J. Diet. Pract. Res., 76 (1): 9-14, 2015.

34- LING R.E., HEDGES V. and SULLIVAN P.B.: Nutritional risk in hospitalised children: An assessment of two instruments. e-SPEN Eur. e-J. Clin. Nutr. Metab., 6 (3): 153 7, 2011.

35- MOEENI V., WALLS T. and DAY A.S.: Nutritional status and nutrition risk screening in hospitalized children in New Zealand. Acta Paediatr., 102 (9): 419-23, 2013.

\title{
تقييم الحالة التفذوية فى الآطفال من سن ب إلى ه سنوات منرات

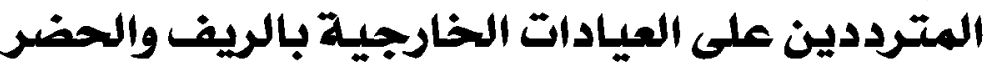

\author{
الخلفية: يتتشر سوء التغذية لدى الآطفال فى البلدان المنخفضة والمتوسطة الدخل. إنه سبب غير مباشر لوفيات الآطفال فى هذه البلدان.

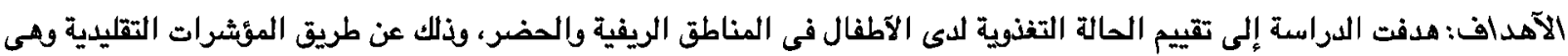

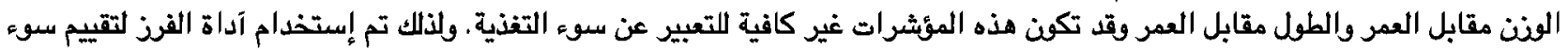 \\ التغذية، وهي آداة آخرى لتقييم الوضع التغذوى لدى الآطفال.
}

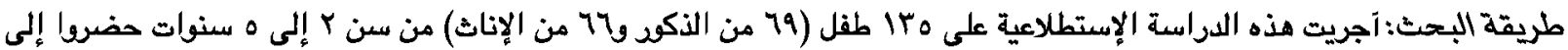

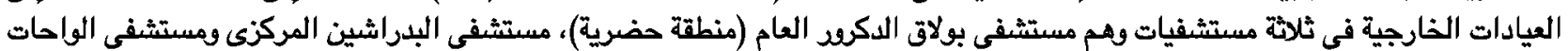

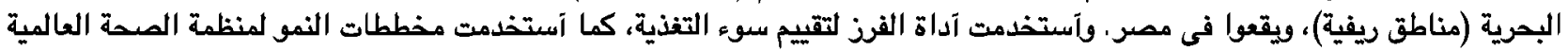

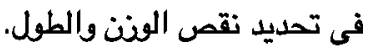

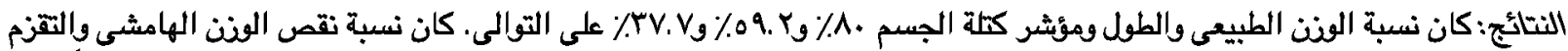

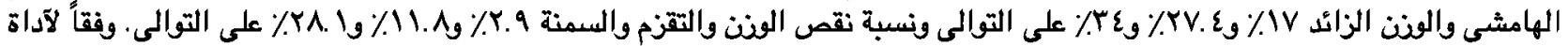

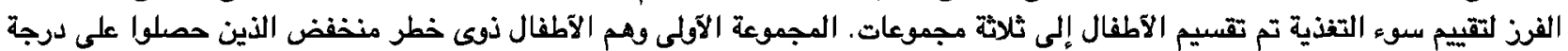

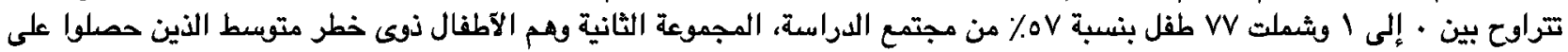

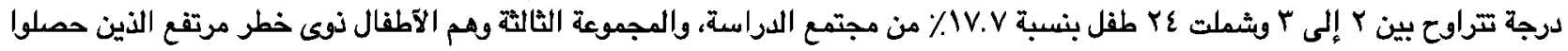

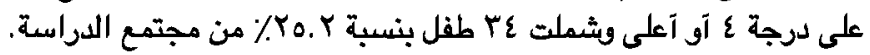
الإستتاجات: يمكن آن يضمن إستخدام آداة الفرز لتقييم سوء التغذية لدى الآطفال التشخيص المبكر لدى الآطفال المعرضين لخطر سوء 